\title{
MARK TWAIN ON TOUR
}

During the last months of 1884 and early 1885, while the first American edition of Adventures of Huckleberry Finn was being readied for publication and book agents were selling subscriptions door-to-door, Mark Twain (Samuel L. Clemens) went on a reading tour in the East and Midwest with his friend and fellow author George Washington Cable. Among Mark Twain's most popular readings were selections from Huckleberry Finn, extracted episodes of which were currently running in the Century Magazine. Reproduced here are the publisher's advertisement for subscription agents, an advertisement for Mark Twain's books currently in print, an official portrait of Mark Twain and Cable made for the reading tour, and three of the reading programs. Four letters from Clemens written while the two authors were on the road follow. In March 1885, one month after the official American publication, the book was banned from the Concord (Massachusetts) Public Library. Mark Twain's first reaction, in a letter to his publisher, is reproduced at the end. 
CONFIDENTIAL THERTS TO AGENTS.

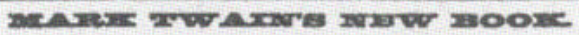

Adventures of Huckleberry Finn.

Tom Sawyer's Companion.

ITMAGNIFICENT AND UNPARALLED OFFER TO CANVASSERS. D

A CHANCE TO MAKE MONEY FOR ALL.

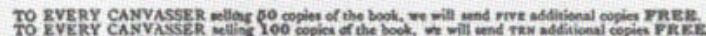

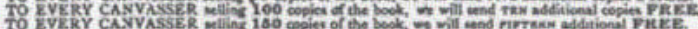

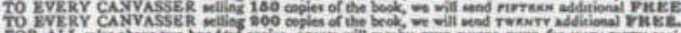

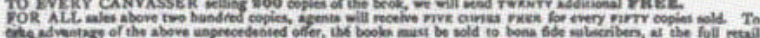

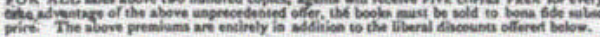

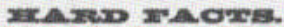

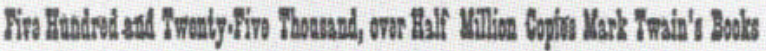

Have been sold in thls councy alone; to ay nothing of the immense wales in Zngland and Oennasy.

Mark Twain's Books are the Quiokest Selling In the World.

a ACENTS: Secure Eacy Work and Sure Pay by Getting a Mark Twain Agenoy.

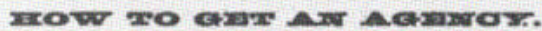

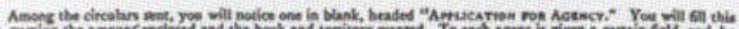
ont, nawinc

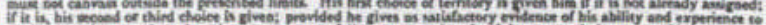

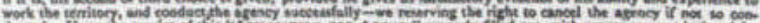

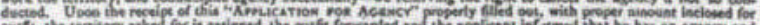

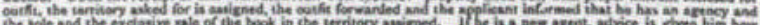

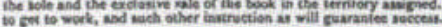

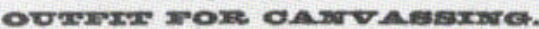

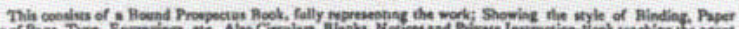

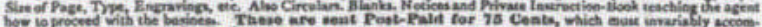

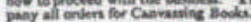

POSITIVELY NO PROSPEOTUSES GIVEN AWAY.

The anount paid for oetfit dedurted on fiest onder of tea er mere cepies. W. Fursileh Hooks toAgeats as Fohowe:

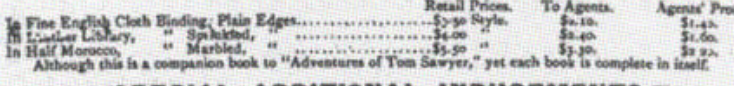
Retail Prices. GSPECIAL ADDITIONAL INDUCEMENTB. T

WE WILL CHARCE YOU NOTHINC FOR PACKINC BOXES. We will furniah all book gives to

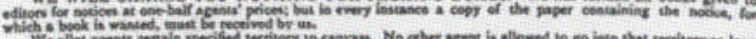

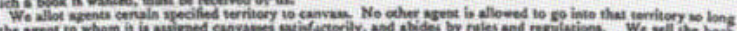

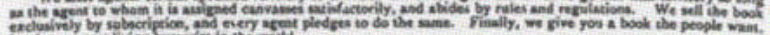

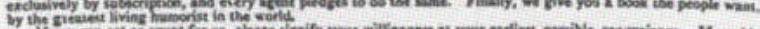

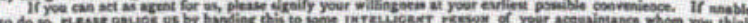

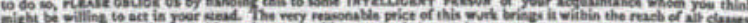

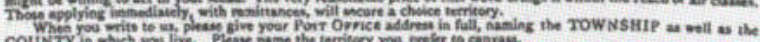

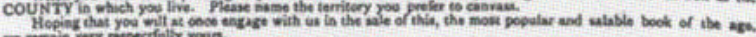
we repinain very respectiatly yours.

OCCIDENTAL PUBLISHING CO.

120 sutter street,

Ban Franclsoo, Cal.

"Confidential Terms to Agents." This flyer, meant to attract local agents to sell Adventures of Huckleberry Finn door-to-door, offered for seventy-five cents an "Outfit for Canvassing," which contained a prospectus (illustrated pages from the book and sample bindings), advertising notices and reviews, and a "Private Instruction-Book teaching the agent how to proceed with the business." The Occidental Publishing Company of San Francisco acted as territorial agents for Mark Twain's publisher, Charles L. Webster \& Company. Courtesy of Ron Randall. 


\section{MARK TWAIN'S COMPLETE WORKS.}

\section{PRICE LIST.}

INNOCBNTS ABROAD; Or, The New Pilgrim's Progrese By: MARK TWAIN. Everybody has heard of this book. Fully Illustratod. 652 Pages, 234 Engravinga Price in Cloth, \$4,00. Leather (library style) 84.75. Half Morooco, 25.50 .

rodghing IT. By Mark Twain. A Companion volugie to Iunocents Abrond. Full of Twain's characteristio humor. 600 Pages, 300 Illastrations.

Price in Cloth, 84.00. Leather (library style) \$4.75. Half Moroceo, 85.50. SKETCHES OLD AND NEW. By Mark Twain. Among them the story of the Jumping Frog. A beautiful purior table book. 320 Pages, 120 mlustrations. Price in Cloth, \$3.50. Leather (library atyle) \$4.00. Falf Moroco0, \$5.50. ADVENTURES OF TOM SAWYER. By Mark Twain. 150 Engravings, New, bright and refroahing. A splendid Git Book.

Prioe in Cloth, 83.50. Libary, 84.00. Half Morocoo, 85.50,

THE GILDED AGE. By Mark Twain and Charlen Dadley Warner. A tale of Tu-day. Wit, Humor and Romance combined. 576 Pages, 212 Illustrations, Prioe in Cloth, 84.00. Leather (library style) 84.75. Half Morocco, 85.50.

A TRAMP ABROAD. Mark Twain in Europe. A Compasion volume to Innoconts Abrod; 631 Pages. Fine Steel Portrait of the author, and 397 other Bngmvings.

Price in Cloth, 84.00. Library, 84.7t. Fall Morocoo, 88.00. THE PRINCE AND THE PAUPER.

Price in Cloth, plain odges, 83.50. Leather, \$4.00. Half Calf or Morocoo, 85.50. ThE stolen WhITE ELEPHANT, BTC. 1 volume, 16 mo. Priee, 81.50. LIFE ON THE MISSISSIPPL. 1 vol., 8va, 600 Pages, 316 Illustrations. Price in Extra Cloth, black snd Gold, plain edgea 84.00. Leather, library binding, marbled edges, \$4.75. Half Calf or Half Monoceo, marbled edgos \$5.50.

25. Although some of the above books havn been publiahed many years, yet resulta shows that they atill sell better than moat new books by other nuthors.

DI8COUNT TO ACENTS ON ABOVE BOOK8, 40 per cent off. ADDRHSS

OCCIDENTAT PUBLISHING CO. 120 SUTTER STREET, BAN FRANCIBCO, CAL.

On the back of the flyer, the Occidental Publishing Company also provided a list of "Mark Twain's Complete Works," published by the American Publishing Company and James R. Osgood and Company, and offered local agents a 40 percent discount, which would effectively give them a profit of 40 percent of the cover price upon sale of the books. Courtesy of Ron Randall. 


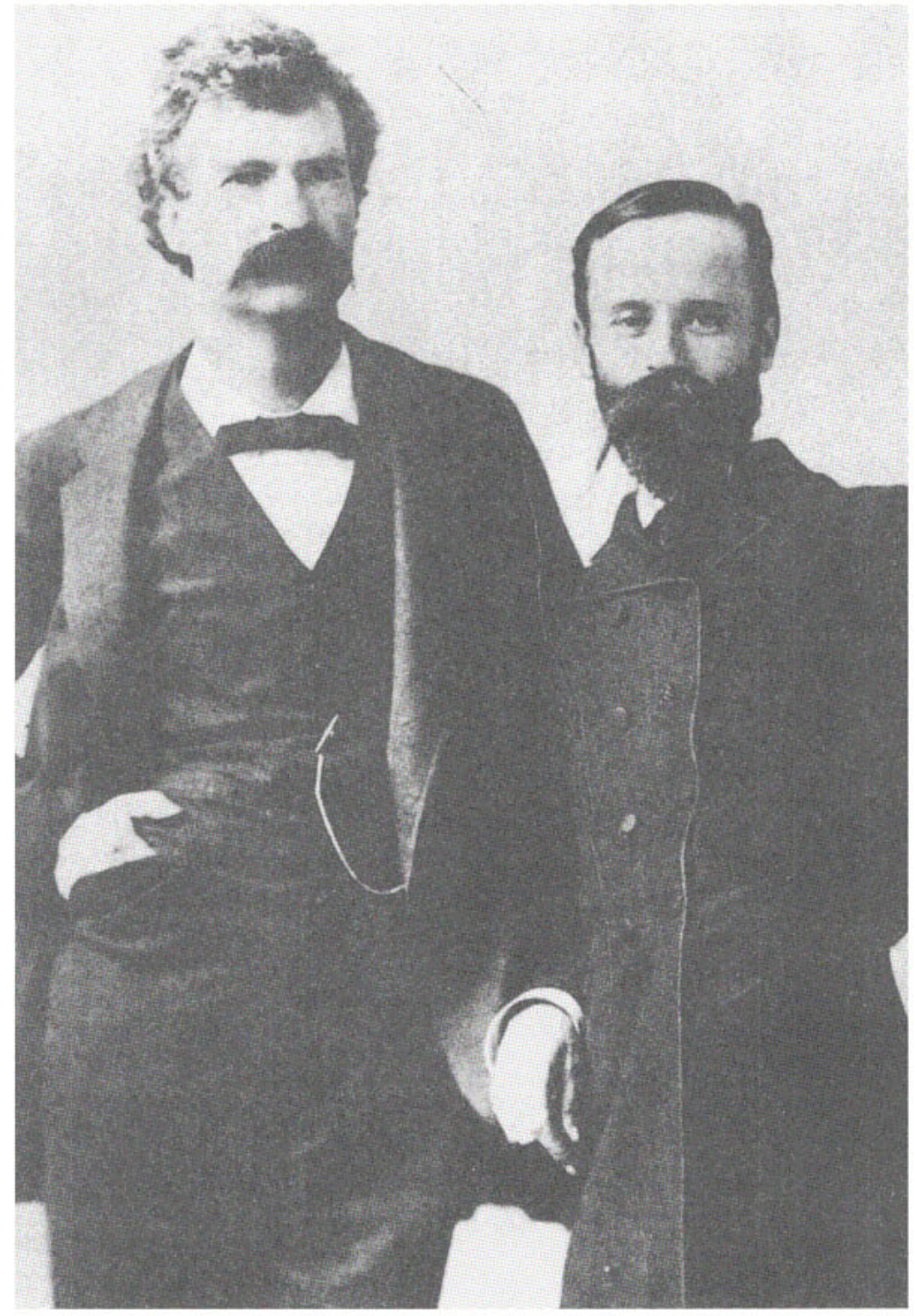

Mark Twain and George Washington Cable in 1884, prior to their joint speaking tour. Photograph by Napoleon Sarony, New York. Mark Twain Papers, The Bancroft Library (CU-MARK). 


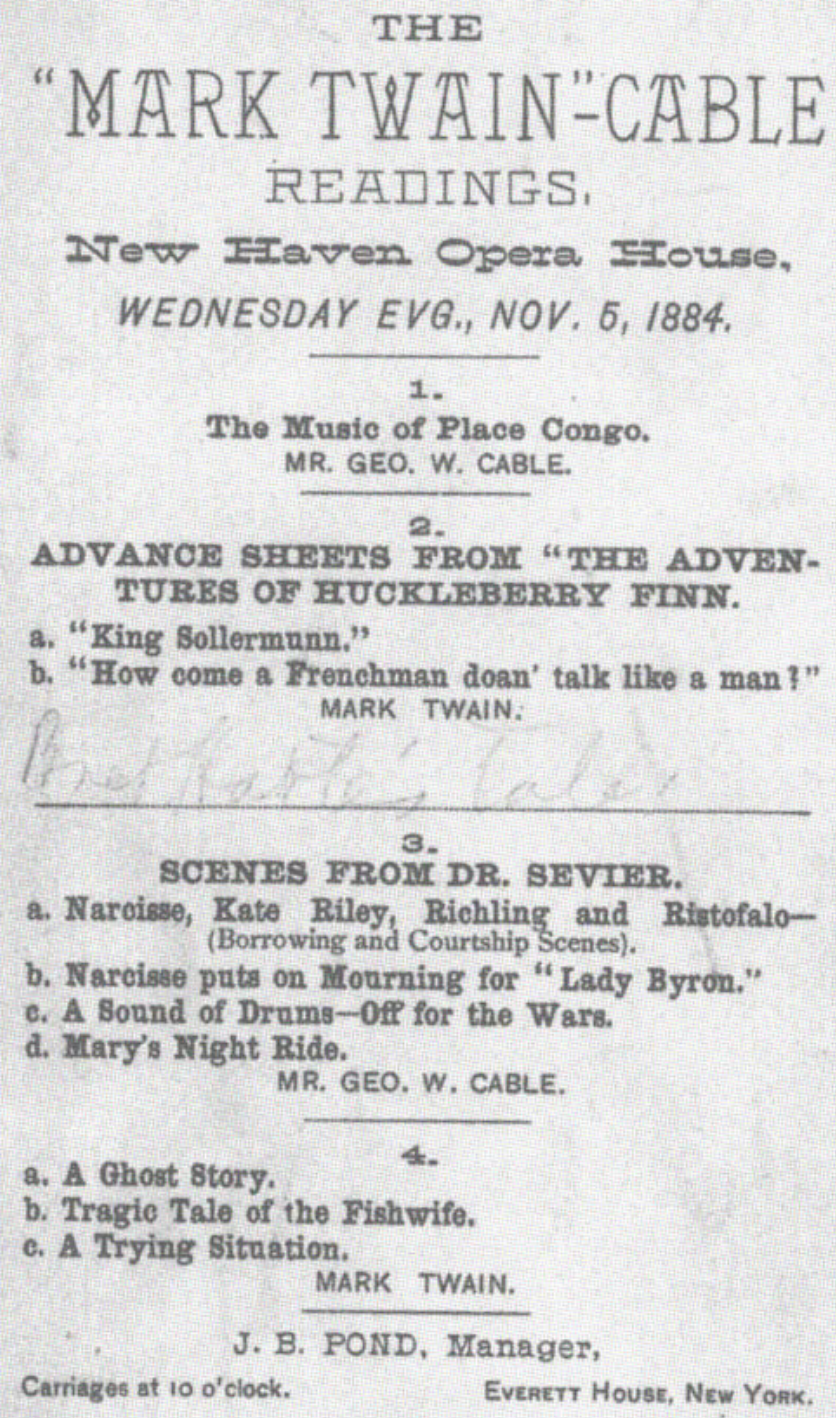

b. "How come a Frenchman doan' talk like a man ?" MARK TWAIN:

a. A Ghost 8tory.

SCINES FROM DR. SEVIER.

a. Naroisse, Kate Riley, Richling and Ristofalo(Borrowing and Courtship Scenes).

b. Narcisse puts on Mourning for "Lady Byron."

c. A Sound of Drums-OIf for the Wars.

d. Mary's Night Ride.

MR. GEO, W. CABLE.

b. Tragie Tale of the Fishwife.

c. A Trying Situation.

\section{4.}

MARK TWAIN.

J. B. POND, Manager,

Carriages at 10 o'clock.

Eveaett House, New York.

"The 'Mark Twain'-Cable Readings." Program from the New Haven, Connecticut, Opera House, 5 November 1884, the first reading of the tour ( 5 Nov 84 to Chatto and Windus, ViU). Mark Twain wrote "Bret Harte's tale" in faint pencil. Mark Twain Papers, The Bancroft Library (CU-MARK). 


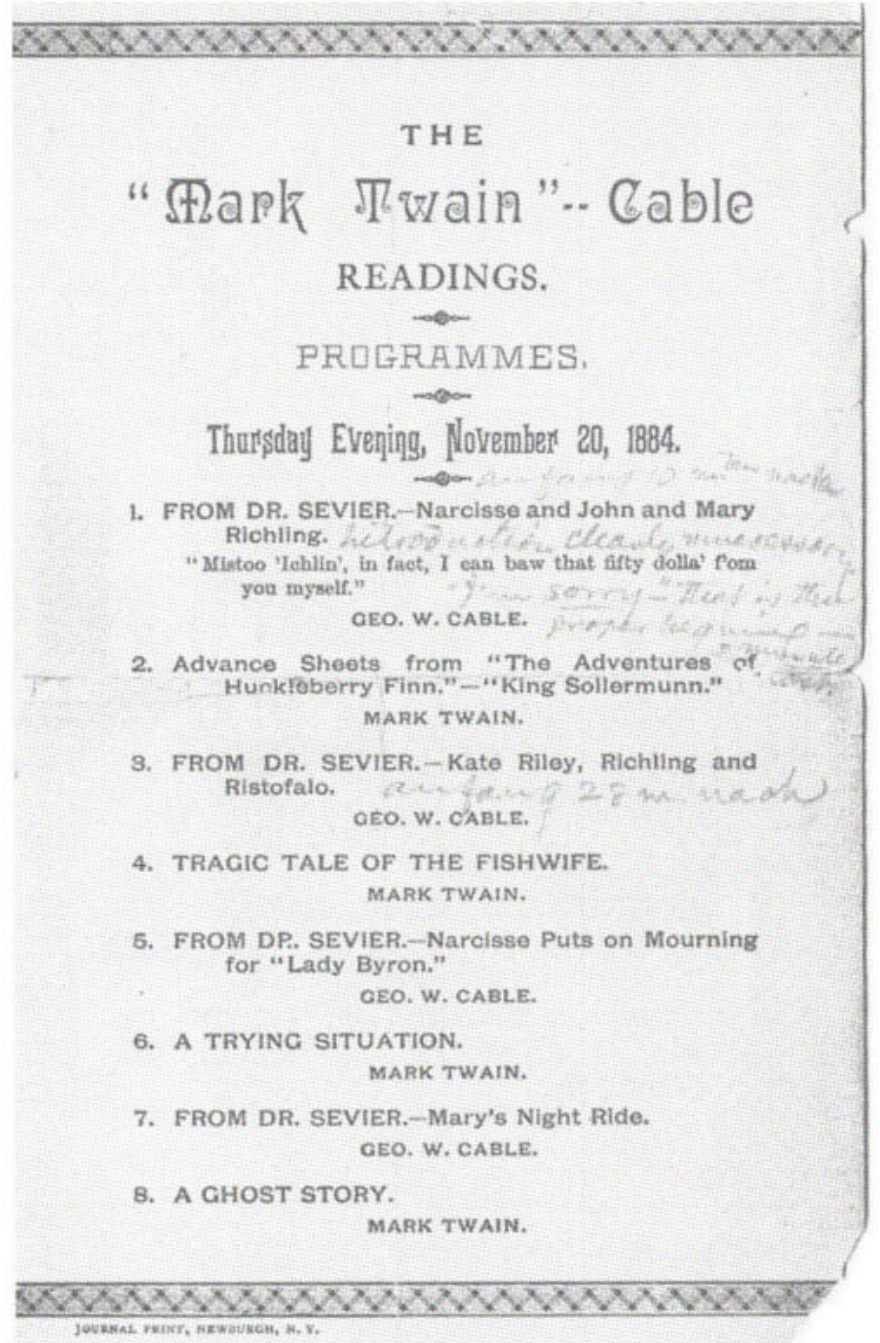

"The 'Mark Twain'-Cable Readings." Program from Newburgh, New York, 20 November 1884. Cable wrote his wife that he had struck "a new streak" at that night's reading, while Clemens showed some annoyance at the growing length of the program, as witnessed by his notes written here (loosely translated): "anfang $10 \mathrm{~m}^{\text {ten }}$ nach" (begun 10 minutes behind); "Introduction clearly unnecessary."; "I'm sorry'-that is the proper beginning-5 minute[s] lost."; "anfang $28 \mathrm{~m}$. nach" (begun 28 minutes behind) (Cardwell, 21-22; Bikle, 133; see HF2003, 578-616). Mark Twain Papers, The Bancroft Library (CU-MARK). 


\section{GENMRAL @USIG நุALL.}

\section{TEX \\ "Mark T'wain"-Gable Readings,}

Saturday Afternoon, January 17 th, 1885.

\section{PRDGRAMME,}

1. FROM DR. SEVIER,-Narcisse and John and Mary Richling. "Mistoo 'Ichlin', in fact, I can baw that fifty dolla' f'om you myself."

GEO, W. CABLE,

2. ADVANCE SHEETS FROM "THE ADVENTURES OF HUCKLEBERRY FINN."-"King Sollermann." MARK TWAXN, end al as 3.

3. FROM DR. SEVIER,-Kate Riley, Richling and Ristofalo, GEO. W. OABLR.

4. Tragic Tale of the Fishwife.

MIRK TWAIN.

5. FROM DR. SEVIER.-Narcisse puts on mourning for "Lady Bynon."

GEO. W. OABLE.

6. A Trying Situation.

MARK TWATN.

7. FROM DR. SEVIER,-Mary's Night Ride.

8. Selection.

GEO, W. CABEE.

MARK THATN.

"Marx Twaix" and Mr. CaBle will appear for the last time in Chicago, this evening, with an entirely new programme.

J. B. POND, MaNhege, Eveest Houge, New York.

carriags AT 10

"The 'Mark Twain'-Cable Readings." Program from the Central Music Hall, Chicago, 17 January 1885. Mark Twain wrote "ended at 3." after his first selection, and "ended at 3.16" after Cable's second selection. Mark Twain Papers, The Bancroft Library (CU-MARK). 


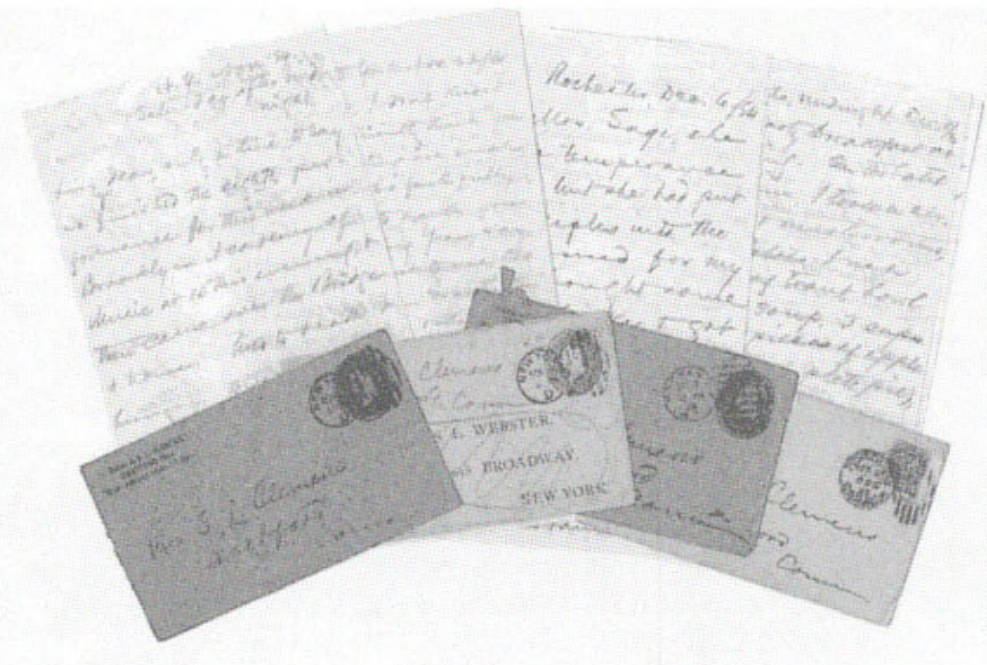

FOUR LETTERS FROM MARK TWAIN

Samuel Clemens wrote three of the following four letters to his wife, Olivia, and the fourth to his eldest daughter, Susy, while on his speaking tour with George Washington Cable in 1884-85. Mentioned in the letters are his three daughters, Olivia Susan (Susy), Clara (Ben), and Jean; the Congregationalist minister and social reformer Henry Ward Beecher; the lawyer and lumber merchant Dean Sage and his wife, Sarah Manning Sage, who acted as Clemens's hostess in Rochester in December; the former president Ulysses S. Grant and his wife, Julia Dent Grant; and the author and Civil War general Lew Wallace. All the letters are in the Mark Twain Papers, The Bancroft Library (CU-MARK).

To Olivia L. Clemens

23 November $1884 \cdot$ New York, N.Y.

N.Y., Nov. '84.

Saturday, after midnight.

Livy dear, only a line to say we finished the eighth performance for this week in Brooklyn Academy of Music at 10 this evening, \& then came over the Bridge $\&$ home. Tired to death, \& hungry. Disposed of two great chops, 3 eggs, fried potatoes, $\&$ a bottle of ale. I eat a big breakfast every morning $\&$ a big supper every night, \& am growing fat. We got up at 6 this morning, $\&$ have talked to two huge houses in Brooklyn today. Mr. Beecher \& the Sages were there tonight, $\&$ Dean came behind the scenes. 
Thank those dear sweet children for me, for their welcome letters. I love them \& their mother.

Saml

\section{To Olivia Susan (Susy) Clemens}

23 November $1884 \cdot$ New York, N.Y.

New York Nov. 23/84.

Susie dear, I don't know how to sufficiently thank you \& Ben for writing me such good letters \& so faithfully. And I want to thank you both for making Jean say things to be sent to me, too. I called at Gen. Grant's the other morning, \& when I saw all his swords, \& medals, \& collections of beautiful \& rare things from Japan $\&$ China, I was so sorry I hadn't made Mamma go with me. And Mrs. Grant was sorry, too, \& made me promise that I would bring Mamma there to luncheon, some time. Gen. Lew Wallace was there-he has an article in this month's Century about the great Victory of Fort Donelson $-\&$ when I told him Mamma was at the reading the other night $\&$ was sorry I didn't make her acquainted with the author of Ben Hur, he was very sorry I was so heedless himself. Mrs. Grant got up \& stood between Gen Wallace \& me, \& said, "There, there's many a woman in this land that would like to be in my place $\&$ be able to tell her children that she had stood once elbow to elbow between two such great authors as Mark Twain \& General Wallace." We all laughed \& I said to Gen. Grant; "Don't look so cowed, General; you have written a book, too, $\&$ when it is published you can hold up your head \& let on to be a person of consequence yourself."

Kiss 'em all for me, sweetheart- $\&$ I send love $\&$ kisses to you, too.

Papa

\section{To Olivia L. Clemens}

6 December $1884 \cdot 2$ nd of $2 \cdot$ Rochester, N.Y.

Rochester, Dec. 6./84

Poor Mrs. Sage, she keeps a temperance house, but she had put her principles into the background for my sake, \& bought some Scotch whisky \& got everything ready for my traditional punch. It almost tempted me to take a drink, but she allowed me to decline without any serious urging.

It has rained cats $\&$ dogs here all day $-\&$ of course it was one of those accursed Matinée days. The houses were good but not crowded, \& we made them shout. I wore that coat for the first time $-\&$ the last. It will go back to you by express. I shall never wear anything but evening dress again. I will not defer to fashion to the destruction of my comfort.

Goodbye, I love you darling, 


\section{To Olivia L. Clemens}

9 December $1884 \cdot 1$ st of $2 \cdot$ Toronto, Canada

Toronto, midnight, Dec. 8/84.

I ate a hearty breakfast at 9 this morning. On the hotel car at 1 p.m., I took a sirloin steak \& mushrooms, sweet potatoes, Irish ditto, plate of trout, bowl of tomato soup, 3 cups of coffee, 4 pieces of apple pie (or one complete pie), 2 plates of ice cream \& 1 orange. But I stopped then, on account of the expense, although still hungry.

To-night a noble hall to talk in, \& an audience befitting it. Both of us had a gorgeously good time. I saw ladies swabbing their eyes freely $\&$ undisguisedly after Cable's "Night Ride." He did it well.

After the performance we came down \& tagged along behind the audience, halting to be introduced to people, $\&$ a most gentle-faced attractive girl in black kept looking back as if she were trying to muster pluck enough to speak to me; $\&$ finally she stopped, hesitated, her party heartened her up, \& she came to me $\&$ put out her hand \& said with a little tremor of fright in her voice, "Don't you remember me, Mr. Clemens?" (It was her joke-I had been reciting "A Trying Situation"). I said, "No, but I do wish I did. But I'll remember you next timedon't you be afraid about that." Then she thanked me timidly but very nicely for the evening's entertainment, \& then re-joined her father $\&$ sister, \& they all seemed pleased with her- $\&$ so was I. It was a very pleasant adventure.

I got Susie's letter, which was ever so welcome; $\&$ yours, too, which was also most welcome; \& so I have sent you a telegram to tell you the hoarseness is utterly gone-I f flled that huge hall to-night with not even an effort.

I love you my darling, I do indeed. And I send love to mother $\&$ to those little chaps, too.

Saml.

I have just finished a robust supper, of beefsteak \&c. I travel 6 or 8 hours by rail without the slightest touch of weariness.

\section{(Opposite)}

Dear Charley-

The Committee of the Public Library of Concord, Mass., have given us a rattling tip-top puff which will go into every paper in the country. They have expelled Huck from their library as "trash \& suitable only for the slums." That will sell 25,000 copies for us, sure.

Ys 


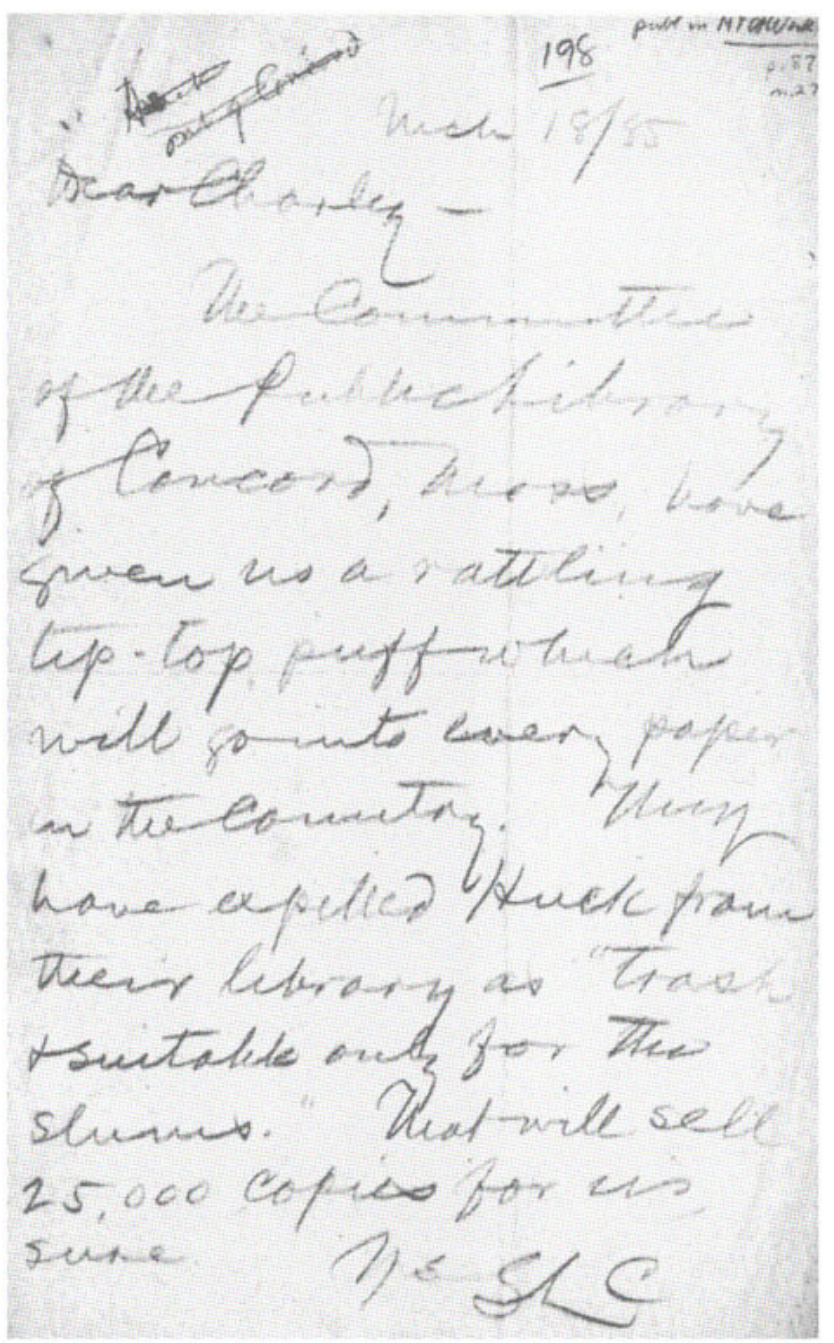

On 18 March 1885, just after the newspapers reported that Adventures of Huckleberry Finn had been removed from the shelves of the Concord Public Library, Clemens wrote this letter to his publisher, Charles L. Webster. Subsequently, however, when a nationwide debate broke out about the book's (and the author's) morality, Clemens was less amused. Mark Twain Papers, The Bancroft Library (CU-MARK). The writing in the top margin is by Mark Twain's biographer, Albert Bigelow Paine, who wrote and canceled "Huck out of Concord," and by subsequent editors. 
